\title{
Genetic diversity of the coat protein of olive latent virus 1 isolates
}

\author{
C. M. R. Varanda $\cdot$ G. Nolasco $\cdot$ M. I. Clara \\ M. R. Félix
}

Received: 6 September 2013/ Accepted: 16 November 2013/Published online: 19 December 2013

(C) Springer-Verlag Wien 2013

\begin{abstract}
The CP gene variability among 21 olive latent virus $1(\mathrm{OLV}-1)$ isolates obtained from different hosts and locations and at different times was assessed. Amplicons obtained by RT-PCR were cloned, and at least 10 sequences from each isolate were analyzed and compared. OLV-1 sequences available in GenBank were included. The encoded CPs consisted of 270 amino acids, except those of isolates G1S and C7 (269 aa) and G6 (271 aa). Comparison of $\mathrm{CP}$ genomic sequences of the isolates under study showed very low values of nucleotide diversity, 0.02 , and maximum nucleotide distances between (0.087) or within isolates (0.001). Although very few nucleotide sequence differences were observed among the isolates, olive isolates exhibited lower diversity (0.012). In addition, at position 158 (157 in C7 and G1S and 159 in G6) of the deduced aa sequences, an alanine residue was found to be conserved among the olive isolates. In citrus and tulip isolates, a threonine residue was present at position 158 , whereas a valine was present at this same position in tomato isolates. Phylogenetic analysis indicated that OLV-1 isolates clustered in five groups according to original host. However, G6, originally recovered from olive but repeatedly inoculated and maintained in $N$. benthamiana plants for 8 years in our laboratory, was separated from other isolates. This may be attributable to adaptation to the experimental host over time. There was no
\end{abstract}

C. M. R. Varanda $(\bowtie) \cdot$ M. I. Clara · M. R. Félix

Laboratório de Virologia Vegetal, Instituto de Ciências Agrárias e Ambientais Mediterrânicas, Universidade de Évora, Apartado 94, 7002-554 Évora, Portugal

e-mail: carlavaranda@uevora.pt

G. Nolasco

Laboratório de Virologia Vegetal, Universidade do Algarve, Campus de Gambelas, 8005-139 Faro, Portugal correlation of phylogenetic grouping of isolates based on geographical location or year of collection. Strong negative selection may have contributed to the low diversity among the OLV-1 CP isolates.

\section{Introduction}

Olive latent virus 1 (OLV-1) belongs to the genus Alphanecrovirus, family Tombusviridae, and was first detected in olive (Olea europaea L.) trees growing in southern Italy [15]. Since then, OLV-1 has been detected in olive trees in other countries, where it either causes no symptoms or is associated with low vigor, dwarfing, bushy growth, fasciation and bifurcation of stems, or yellow and sickle-shaped leaves $[1,7-9,25,36,42]$. OLV-1 also has been shown to be associated with chlorotic dwarf disease of citrus in Turkey, with necrosis of tulips in Japan, and necrosis of tomato in Poland [2, 20, 26]. OLV-1 can infect a range of herbaceous hosts, causing chlorotic, necrotic or reddish local lesions [13]. OLV-1 causes systemic mosaic in $N$. benthamiana [15, 27]. The Portuguese OLV-1 isolate GM6 seldom causes systemic leaf mosaic, but co-inoculation with olive mild mosaic virus (OMMV) results in systemic invasion of $N$. benthamiana by both necroviruses [4, 12]. OLV-1 has been detected in all plant organs, from roots to seeds, as well as free in soil and plant growth substrate [10, $24,35,39$ ], which are important sources for virus spread in nature.

Complete genome sequences of OLV-1 recovered from citrus [17], olive [11] and tomato [19] are available, as well as a partial sequence that includes the coat protein $(\mathrm{CP})$ gene of a tulip OLV-1 isolate [20]. OLV-1 has a positivesense single-stranded RNA genome of about $3.7 \mathrm{~kb}$ containing 5 ORFs. The 5'-proximal ORF1 encodes a $23-\mathrm{kDa}$ 
polypeptide that is predicted to be involved in RNA replication. ORF1 RT results from readthrough of an amber stop codon, generating an $82-\mathrm{kDa}$ product identified as the RNA-dependent RNA polymerase (RdRp). ORF2 and ORF3 encode small peptides of $8 \mathrm{kDa}$ and $6 \mathrm{kDa}$, respectively, which are predicted to be involved in viral movement. The 3'-proximal gene, ORF 4, encodes the $30-\mathrm{kDa} \mathrm{CP}$, which is essential for virus assembly and systemic spread [30].

Most CPs of plant icosahedral positive-stranded RNA viruses have four distinct structural domains: an ' $R$ ' domain involved in the interaction with RNA, a connecting arm ' $a$ ', a central shell domain ' $\mathrm{S}$ ' and a C-terminal projecting ' $\mathrm{P}$ ' domain. Necroviruses lack the ' $\mathrm{P}$ ' domain $[6$, 28]. For OLV-1 CP, only the ' $S$ ' domain has been identified, covering positions 53 to 270 [11]. The ' $S$ ' domain in icosahedral viruses has a signature pattern, consisting of a 26 amino acid residues located at OLV-1 CP aa positions 135-160 ([FYW]-x-[PSTA]-x(7)-G-x-[LIVM]-x-[LIVM]$x-[F Y W I L]-x(2)-D-x(5)-P)$ [13] and includes four sites likely to be involved in $\mathrm{Ca}^{2+}$ binding [17, 29].

RNA viruses have potential for high genetic diversity due to the lack of proofreading activity of the RdRp, conferring a high potential for adaptation and evolution. However, selective pressures imposed by certain aspects of viral biology (e.g., host type and range) may limit genetic diversity [31, 33, 34, 40, 41].

Here, we studied the diversity of OLV-1 by molecular analysis of the $\mathrm{CP}$ gene of isolates obtained from different hosts and locations. We believe this will allow a deeper knowledge of virus populations and facilitate understanding of the epidemiology of this widely disseminated virus. The study of virus diversity also will contribute to design of more efficient and durable diagnostic methods.

\section{Materials and methods}

\section{Virus isolates}

Twenty-one OLV-1 isolates were characterized in this study: 16 from Portugal, two from Poland, two from Croatia and one from Italy (Table 1). Most of the isolates were from olive (18), but two were isolated from tomato, and one isolate was recovered from citrus. Four additional OLV-1 CP gene sequences were retrieved from GenBank: original host and locations were Turkey (citrus), Portugal (olive), Poland (tomato) and Japan (tulip) (Table 1). OLV1 isolate G6 is the result of repeated passage of isolate GM6 through the experimental host $N$. benthamiana for the last eight years. All isolates were maintained in $N$. benthamiana plants following mechanical inoculation of olive fruit extracts in the presence of $0.05 \mathrm{M}$ sodium phosphate buffer, with the exception of those from Poland and Croatia and OlivMitra (Portugal), which were recovered from 2-year olive stem scrapings and used directly as a source for nucleic acid extraction.

Nucleic acid extraction

Total RNA was extracted from $100 \mathrm{mg}$ of symptomatic leaves of $N$. benthamiana plants macerated in liquid nitrogen, using an RNeasy Plant Mini Kit (QIAGEN) following manufacturer's instructions. Double-stranded (ds) RNA was extracted from $10 \mathrm{~g}$ of olive stem scrapings essentially as described by Valverde et al. [38], denatured for $5 \mathrm{~min}$ at $100{ }^{\circ} \mathrm{C}$ and then placed on ice for $15 \mathrm{~min}$ prior to $\mathrm{RT}$-PCR reactions.

\section{RT-PCR}

For cDNA synthesis, $1 \mu \mathrm{g}$ of total RNA or $1 \mu \mathrm{g}$ of denatured dsRNA was used in a $20-\mu \mathrm{L}$ reaction with $200 \mathrm{U}$ of M-MLV reverse transcriptase (Invitrogen) in the presence of random hexamers (Promega) and 1x first-strand buffer (Invitrogen), in accordance with the manufacturer's instructions. For PCR, specific primers encompassing the CP ORF (OLV1coat5', GACATTTCGCAACTCTCT, and OLV1coat3', CACAACGATGGGTGAGTTGC) were designed based on OLV-1 genomic sequences available in GenBank. One microliter of cDNA was used in a $50-\mu \mathrm{L}$ reaction with $2.5 \mathrm{U}$ of FideliTaqDNA Polymerase (USB

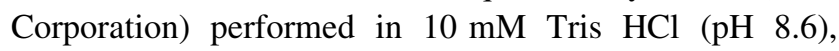
$50 \mathrm{mM} \mathrm{KCl}, 1.5 \mathrm{mM} \mathrm{MgCl}_{2}, 0.2 \mathrm{mM}$ dNTPs and $0.3 \mu \mathrm{M}$ of each primer. Amplifications were carried out in a Thermal Cycler (Bio-Rad) following initial denaturation at $94{ }^{\circ} \mathrm{C}$ for $1 \mathrm{~min}, 35$ cycles at $94{ }^{\circ} \mathrm{C}$ for 30 seconds, $53{ }^{\circ} \mathrm{C}$ for $1 \mathrm{~min}$ and $68{ }^{\circ} \mathrm{C}$ for $1 \mathrm{~min}$ and 30 seconds, and a final extension step of $68{ }^{\circ} \mathrm{C}$ for $5 \mathrm{~min}$. The use of these primers in RT-PCR assays produces a fragment of $\approx 857 \mathrm{nt}$.

Cloning and sequence analysis

RT-PCR products were purified using a GFX PCR DNA Purification kit (GE Healthcare Biosciences) and cloned into pGEM-T Easy Vector (Promega) according to the manufacturer's instructions. Plasmid DNA was extracted from Escherichia coli cells using a GenElute ${ }^{\mathrm{TM}}$ HP Plasmid Miniprep Kit (Sigma) following manufacturer's instructions after growing cells (overnight, $37{ }^{\circ} \mathrm{C}, 175 \mathrm{rpm}$ ) in low-salt LB medium ( $1 \%$ tryptone, $0.5 \%$ yeast extract, $0.5 \% \mathrm{NaCl}, \mathrm{pH} 7.5$ ) supplemented with $100 \mu \mathrm{g}$ of ampicillin per $\mathrm{mL}$. DNA sequencing reactions were performed on both strands by Macrogen (The Netherlands). Sequences of at least ten clones of each isolate were determined. These, as well as four OLV-1 CP gene sequences available 
Table 1 Olive latent virus 1 isolates and OLV-1 sequences retrieved from GenBank

\begin{tabular}{|c|c|c|c|c|c|}
\hline Isolate & Origin & Crop/cul & ltivar & Year of collection & Accession number \\
\hline Oliv Mitra & South Portugal & Olive & Galega vulgar & 2012 & KF804065 \\
\hline G1PB & & & & 1995 & KF804051 \\
\hline G1S & & & & & KF804052 \\
\hline G3S & & & & & KF804053 \\
\hline G6 & & & & & KF804054 \\
\hline G1A & & & & & KF804056 \\
\hline $\mathrm{G} 2 \mathrm{~A}$ & & & & & KF804057 \\
\hline G5A & & & & & KF804058 \\
\hline G8 M & & & & & KF804059 \\
\hline V6 & & & Verdeal alentejana & & KF804062 \\
\hline V10 & & & & & KF804063 \\
\hline C1VM & & & Cordovil & & KF804055 \\
\hline $\mathrm{C} 7$ & & & & & KF804061 \\
\hline $\mathrm{A} 4 \mathrm{P} 2$ & North Portugal & & Santulhana & & KF804064 \\
\hline $\mathrm{A} 1 \mathrm{P} 2$ & & & & & KF804066 \\
\hline Negr & & & Negrinha de Freixo & & KF804060 \\
\hline Croatia1 & Croatia & & Rosinjola & 2012 & KF804067 \\
\hline Croatia2 & & & Buza Puntoza & & KF804068 \\
\hline OLV1it & Turkey & Citrus & & 1996 & KF804048 \\
\hline Poltom & Poland & Tomato & & 2009 & KF804049 \\
\hline Polbenth & & & & & KF804050 \\
\hline GM6 & South Portugal & Olive & Galega vulgar & 1995 & DQ083996 \\
\hline OLV1c & Turkey & Citrus & & 1996 & NC_001721 \\
\hline CM1 & Poland & Tomato & & 2010 & GU326337 \\
\hline Pare-P & Japan & Tulip & & 2001 & AB061815 \\
\hline
\end{tabular}

from GenBank (Table 1) were compared. The search for homologous sequences was done using BLAST. A multiple sequence alignment was generated using BioEdit 7.1.3.0 [18] and CLUSTAL W in MEGA 5.1 software [37]. The best-fit nucleotide substitution model for these data was the Kimura 2-parameter model in the MEGA 5.1 software, showing the lowest Bayesian information criterion (BIC) score. This model was used to estimate nucleotide distance, diversity and phylogenetic relationships, which were inferred using the neighbor-joining (NJ) method. All sequences, including repeated ones, were used for estimation of genetic diversity. To confirm the results of phylogenetic analysis using the $\mathrm{NJ}$ method, trees were produced using the Minimum Evolution, Maximum Parsimony and Maximum Likelihood methods in the MEGA 5.1 software. Bootstrap analyses with 1000 replicates were performed to evaluate the significance of nodes. Phylogenetic analysis was performed using a consensus sequence for each isolate based on sequences derived from at least 10 clones. Recombination events were evaluated by RDP, GENECONV, Bootscan, Chimaera, 3Seq and SiSCAN in the RDP4.18 software, using default settings and a Bonferronicorrected highest $P$-value of 0.05 . To identify specific amino acid sites under selective constraints, the difference between nonsynonymous $\left(\mathrm{d}_{\mathrm{N}}\right)$ and synonymous $\left(\mathrm{d}_{\mathrm{S}}\right)$ substitution rates was estimated for each position in the alignments using the REL method as implemented in the HYPHY server (http://www.datamonkey.org) [21].

\section{Results}

Amplified RT-PCR products were of the expected size ( $\approx 857 \mathrm{bp}$ ). The $\mathrm{CP}$ sequences of $21 \mathrm{OLV}-1$ isolates $(11$, 12, 19 and 21 clones from G1A, G5A, G6 and G3S, respectively, and 10 clones from the other isolates) and the four OLV-1 CP gene sequences available from GenBank (totaling 237 sequences) were compared.

All sequences encoding the OLV-1 CP encoded 270 aa, with the exception of isolates G1S and C7 (269 aa) and isolate G6 (271 aa). Pairwise distances for all OLV-1 sequences ranged from 0.000 to 0.086 . A lower pairwise distance range $(0.000-0.037)$ was observed among isolates originating from olive. Isolates that showed the lowest pairwise distance (0.000) were OlivMitra and G3S; highest pairwise distances were observed among isolates from different hosts, G6 and Poltom or Polbenth, and G6 and OLV-1c. The genetic distance values within isolates were 


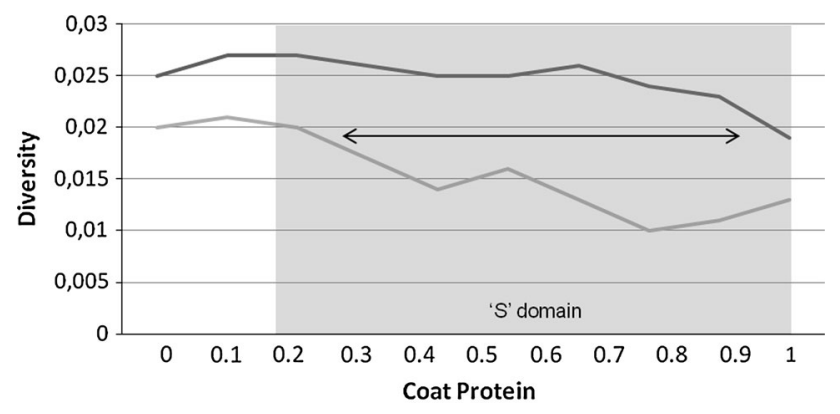

- nucleotide diversity — deduced aminoacid diversity

Fig. 1 Nucleotide and deduced amino acid sequence diversity along the OLV-1 CP gene. Nucleotide sequence diversity was examined in successive windows of $81 \mathrm{nt}$, and amino acid sequence diversity was examined in successive windows of 26 aa. The shaded region represents the ' $S$ ' domain. The arrow indicates a decrease in nucleotide and amino acid sequence diversity

very low, averaging 0.001: 0.007 (isolates G2A, G1 PB, G3S), 0.004 (isolates G1A, G1S, G6, C1VM) and 0.000 (all others). Diversity between isolates also was very low, with total diversity mostly due to differences between isolates and not within isolates, as observed by the high coefficient of differentiation of 0.98 (S.E. 0.004). There was not a distinct variable region along the encoded $\mathrm{CP}$ ORF of OLV-1 isolate sequences, although a slight decrease in the nucleotide diversity in the ' $S$ ' domain region was noted (Fig. 1).

The CP ' $\mathrm{S}$ ' domain of OLV-1 starts at aa 53 and ends at aa 270, except for those of isolates G1S and C7 and isolate G6, in which the S domain spans aa 52 to 269 and 54 to 271 aa, respectively. The typical signature pattern for this domain ([FYW]-x-[PSTA]-x(7)-G-x-[LIVM]-x-[LIVM]-x[FYWIL]-X(2)-D-x(5)-P) was detected at 135 to 160 aa (134 to 159 and 136 to 161 aa, for isolates G1S and C7 and isolate G6, respectively). Within the signature pattern, an alanine residue was conserved at position 158 (157 and 159 in isolates G1S and C7 and isolate G6, respectively) of all olive isolates except that of G6. In citrus and tulip isolates, position 158 is occupied by threonine, and in tomato isolates a valine residue is present. In the G6 olive isolate, which was repeatedly passaged in $N$. benthamiana, valine occurred at position 158, similarly to that observed in OLV-1 tomato isolates. This observation suggests that the valine substitution reflects adaptation to solanaceous hosts, which requires further confirmation. No isolates showed variation in the four amino acids predicted to be involved in $\mathrm{Ca}^{2+}$ binding (two residues of aspartic acid [D], one of threonine [T] and one of asparagine [N]) [17, 29].

The CP genes of the OLV-1 isolates under study did not show distinct recombination sites when examined using the RDP software (data not shown), suggesting that recombination had not occurred.
The phylogenetic tree deduced from the alignment of $\mathrm{CP}$ consensus sequences (Fig. 2) revealed segregation of the isolates under study into five clusters. As expected from the matrix of sequence identity, OLV-1 isolates were grouped according to host origin, with the exception of G6.

The difference between $d_{N}$ and $d_{S}$ at each individual codon was statistically tested by the REL method to determine if negative selection affected genetic variability. No positively selected codon was detected, whereas 87 codons were under negative selection (data not shown), suggesting strong negative or purifying selection.

\section{Discussion}

We compared CP sequences of $21 \mathrm{OLV}-1$ isolates originating from different hosts, sites and years. At least 10 complete $\mathrm{CP}$ sequences of each isolate were obtained. Analysis of $\mathrm{CP}$ nt and aa sequences revealed that overall diversity of OLV-1 isolates was low between and within isolates and that total diversity was mostly due to diversity between isolates, as shown by the high coefficient of differentiation. The nucleotide sequence variability within OLV-1 isolates was very low, $<0.7 \%$; $0.1 \%$ on average.

Sequence conservation among the CPs of OLV-1 isolates observed in this study (nt pairwise distance $<0.086$ and genetic diversity 0.02 ) was extremely high. Low CP sequence diversity $(0.03-0.10)$ has been observed for other RNA viruses [16]. Similar studies on other members of the family Tombusviridae, (carnation mottle virus [3] and pelargonium flower break virus [31]) have measured diversity values for $\mathrm{CP}$ sequences of $\approx 0.03$. The fact that in OLV-1, as well as in other members of the genus $A l$ phanecrovirus, the ' $\mathrm{S}$ ' domain is the only $\mathrm{CP}$ domain found, contrary to other viruses of the Tombusviridae, may help to explain the higher stability found. The ' $\mathrm{S}$ ' domain has been shown to be the most conserved region in the $\mathrm{CP}$ of small plant viruses, suggesting that it is the region where more functional or structural constraints are located [31]. This is confirmed in the present work, where we evaluated selective constraints by comparing rates of synonymous and nonsynonymous substitutions across codon sites. No positively selected codons were detected, whereas 87 codons were under negative selection, suggesting that aa changes would result in functional or structural disadvantages, thus indicating strong negative or purifying selection. Negative constraints to which viral CPs are subjected may be due to multiple functions, including genome protection, cell-to-cell movement, transmission between plants, interactions with the host and/or vector, etc. In addition, Chare and Holmes [5] analyzed selection pressures in the capsid genes of plant RNA viruses and found 
Fig. 2 Phylogenetic tree analysis of OLV-1 isolates based on $\mathrm{CP}$ nt consensus sequences. An NJ tree was constructed from the sequence alignment of $\approx 857 \mathrm{nt}$ of the OLV-1 CP coding region from the 21 isolates studied here and from four retrieved from the GenBank database. Eleven, 12, 19 and 21 clones from G1A, G5A, G6 and G3S isolates, respectively, and ten clones from each one of the other isolates were sequenced and used to determine the consensus sequence for each isolate. Phylogenetic analysis included 21 consensus sequences, plus four sequences retrieved from GenBank. Multiple sequence alignments were generated using MEGA 5.1, and a phylogenetic tree was constructed by the NJ algorithm, based on calculations from pairwise nt sequence distances for gene nt analysis. Bootstrap analysis was done with 1000 replicates. Numbers above the lines indicate bootstrap scores out of 1000 replicates

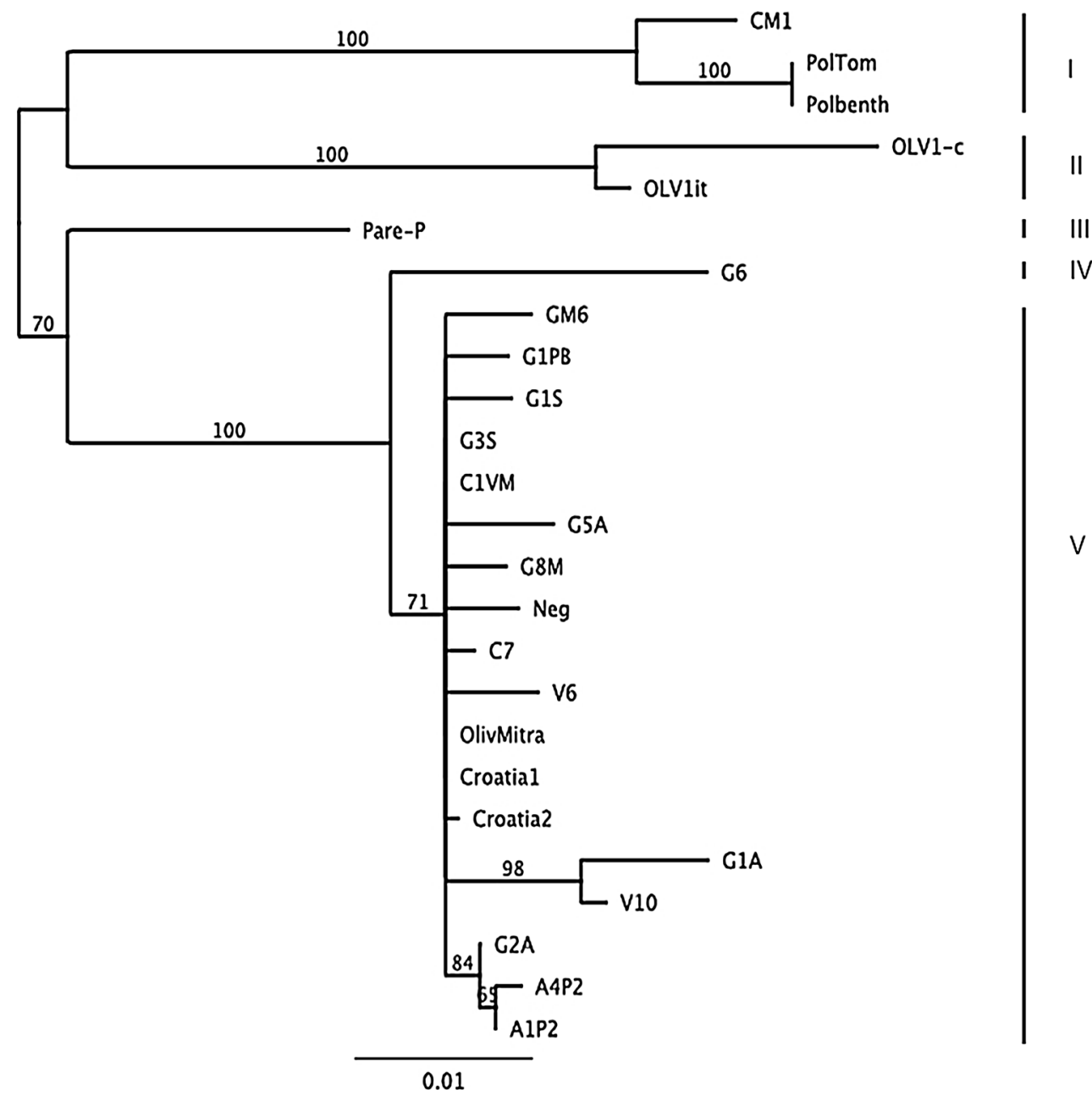

The hypothesis of host adaptation is reinforced by analysis of the phylogenetic tree, which showed OLV-1 isolates segregating in five subgroups (Fig. 2) related to the host of origin. Segregation seems to be related to the host of origin. Clade I is composed of tomato isolates, clade II is composed of citrus isolates, clade III is composed of the tulip isolate, clade IV is composed of the G6 isolate, and clade $\mathrm{V}$ is composed of all other olive OLV-1 isolates used in this study. No relationship was found among isolates according to collection time or spatial separation. These results agree with those of other authors who have reported a high spatial and temporal genetic stability for several RNA viruses, suggesting that selective pressures to preserve biological functions are stronger than speciation due to geographic separation $[14,23,32,34,40]$.

Acknowledgments The authors would like to thank to Sara Godena (Institute of Agriculture and Tourism Poreč, Croatia) and Natacha Borodynko (Institute of Plant Protection, Poznan, Poland) for supplying OLV-1 isolates used in this study. The authors are grateful to Mrs. Maria Mário Azedo for her technical assistance. Carla Marisa R. Varanda is recipient of a postdoctoral fellowship from Fundação para a Ciência e a Tecnologia (FCT), SFRH/BPD/76194/2011. 


\section{References}

1. Alabdullah A, Elbeaino T, Minafra A, Digiaro M, Martelli GP (2009) Detection and variability of olive latent virus 3 in the mediterranean region. J Plant Pathol 91(3):521-525

2. Borodynko N, Hasiów-Jaroszewska B, Pospieszny H (2010) Identification and characterization of an olive latent virus 1 isolate from a new host: Solanum lycopersicum. J. Plant Pathol 92(3):789-792

3. Canizares MC, Marcos JF, Pallás V (2001) Molecular variability of twenty-one geographically distinct isolates of Carnation mottle virus (CarMV) and phylogenetic relationships within the Tombusviridae family. Arch Virol 146:2039-2051

4. Cardoso JMS, Félix MR, Clara MIE, Oliveira S (2005) The complete genome sequence of a new necrovirus isolated from Olea europaea L. Arch Virol 150:815-823

5. Chare ER, Holmes EC (2004) Selection pressure in the capsid genes of plant RNA viruses reflect mode of transmission. J Gen Virol 85:3149-3157

6. Coutts RH, Rigden JE, Slabas AR, Lomonossoff GP, Wise PJ (1991) The complete nucleotide sequence of tobacco necrosis virus strain D. J Gen Virol 72:1521-1529

7. El Air M, Mahfoudi N, Digiaro M, Najjar A, Elbeaino T (2011) Detection of olive-infecting viruses in Tunisia. J Phytopathol 159(4):283-286

8. Fadel C, Digiaro M, Choueiri E, El Beaino T, Saponari M, Savino V, Martelli GP (2005) On the presence and distribution of olive viruses in Lebanon. Bul OEPP/EPPO 35:33-36

9. Félix MR, Clara MIE (1998) Características biológicas e bioquimicas da estirpe G1, do Necrovirus Olive laten 1 isolado de Olea europaea L. Actas da $2^{\text {a }}$ Reunião Bienal da Soc Port de Fitopatol 67

10. Félix MR, Varanda CMR, Cardoso JMS, Clara MIE (2004). Soil transmission of an olive isolate of olive latent virus 1. In: 15th International Plant Protection Congress, Beijing, China, Book of Abstracts $\mathrm{p} 447$

11. Félix MR, Cardoso JMS, Varanda CMR, Oliveira S, Clara MIE (2005) Complete nucleotide sequence of an olive latent virus 1 isolate from olive trees. Arch Virol 150:2403-2406

12. Félix MR, Varanda CMR, Cardoso JMS, Clara MIE (2006) Plant root uptake of olive latent virus 1 and olive mild mosaic virus in single and mixed infections. In: Proceedings of the 12th Congress of the Mediterranean Phytopathological Union, Greece, 516-517

13. Félix MR, Cardoso JMS, Oliveira S, Clara MI (2007) Biological and molecular characterization of olive latent virus 1. Plant Viruses 1:170-177

14. Fraile A, Malpica JM, Aranda MA, Rodriguez-Cerezo E, GarciaArenal F (1996) Genetic diversity in tobacco mild green mosaic tobamovirus infecting the wild plant Nicotiana glauca. Virology 223(1):148-155

15. Gallitelli D, Savino V (1985) Olive latent virus 1, an isometric virus with a single RNA species isolated from olive in Apulia, Southern Italy. Annu Appl Biol 106:295-303

16. Garcia-Arenal F, Fraile A, Malpica JM (2001) Variability and genetic structure of plant virus populations. Annu Rev Phytopathol 39:157-186

17. Grieco F, Savino V, Martelli GP (1996) Nucleotide sequence of the genome of a citrus isolate of olive latent virus 1. Arch Virol 141:825-838

18. Hall TA (1999) BioEdit: a user-friendly biological sequence alignment editor and analysis program for Windows 95/98/NT. Nucl Acids Symp Ser 41:95-98

19. Hasiów-Jaroszewska B, Borodynko N, Pospieszny H (2011) Molecular characterization of the full-length genome of olive latent virus 1 isolated from tomato. J Appl Genet 52(2):245-247
20. Kanematsu S, Taga Y, Morikawa T (2001) Isolation of olive latent virus 1 from tulip in Toyama prefecture. J Gen Plant Pathol 67:333-334

21. Kosakovsky Pond SL, Frost SDW (2005) Not so different after all: a comparison of methods for detecting amino acid sites under selection. Mol Biol Evol 22(5):1208-1222

22. Liang XZ, Lee BTK, Wong SM (2002) Covariation in the capsid protein of Hibiscus chlorotic ringspot virus induced by serial passing in a host that restricts movement leads to avirulence in its systemic host. J Virol 76:12320-12324

23. Lin HX, Rubio L, Smythe A, Jiminez M, Falk B (2003) Genetic diversity and biological variation among California isolates of Cucumber mosaic virus. J Gen Virol 84:249-258

24. Lobão DL, Félix MR, Clara MIE, Oliveira S, Leitão FA, Serrano JF (2002) Detection of Olive latent virus 1 in Olea europaea L. tissues by reverse transcription-polymerase chain reaction. XIII Congresso Nacional de Bioquimíca, p 102

25. Martelli GP, Sabanadzovic S, Savino V, Abu-Zurayk AR, Masannat M (1995) Virus-like disease and viruses of olive in Jordan. Phytopathol Mediterr 34:133-136

26. Martelli GP, Yilmaz MA, Savino V, Baloglu S, Grieco F, Güldür ME, Greco N, Lafortezza R (1996) Properties of a citrus isolate of olive latent virus 1, a new necrovirus. Eur J Plant Pathol 102:527-536

27. Merciega V, Boscia D, Savino V (1996) Comparison of five isolates of olive latent virus 1. Phytopathol Mediterr 35:1-8

28. Meulewaeter F, Seurinck J, Vanemmelo J (1990) Genome structure of Tobacco necrosis virus strain-A. Virology 177:699-709

29. Oda Y, Saeki K, Takahashi Y, Maeda T, Naitow H, Tsukihara T, Fukuyama K (2000) Crystal structure of tobacco necrosis virus at $2.25 \AA$ resolution. J Mol Biol 300:153-169

30. Pantaleo V, Grieco F, Di Franco A, Martelli GP (2006) The role of the $\mathrm{C}$-terminal region of olive latent virus 1 coat protein in the host systemic infection. Arch Virol 151(10):1973-1983

31. Rico P, Ivars P, Elena SF, Hernández C (2006) Insights into the selective pressures restricting Pelargonium flower break virus genome variability: evidence for host adaptation. J Virol 80(16):8124-8132

32. Rodriguez-Cerezo E, Moya A, Garcia-Arenal F (1989) Variability and evolution of the plant RNA virus pepper mild mottle virus. J Virol 63(5):2198-2203

33. Roossinck MJ (1997) Mechanisms of plant virus evolution. Annu Rev Phytopathol 35:191-209

34. Rubio L, Ayllón MA, Kong P, Fernández A, Polek M, Guerri J, Moreno P, Falk BW (2001) Genetic variation of Citrus tristeza virus isolates from California and Spain: evidence for mixed infections and recombination. J Virol 75(17):8054-8062

35. Saponari M, Savino V, Martelli GP (2002) Transmissioni per seme dei virus dell'olivo. Frutticoltura 4:103-105

36. Savino V, Sabanadzovic S, Sacrito G, Laviola C, Martelli GP (1996) Due giallumi dell' olivo di possible origine virale in Sicilia. Inf Fitopatol 5:55-59

37. Tamura K, Peterson D, Peterson N, Stecher G, Nei M, Kumar S (2011) Mega5: Molecular evolutionary genetics analysis using maximum likelihood, evolutionary distance, and maximum parsimony methods. Mol Biol Evol 28(10):2731-2739

38. Valverde RA, Nameth ST, Jordan RL (1990) Analysis of double stranded RNA for plant virus diagnosis. Plant Dis 74:255-258

39. Varanda CMR, Cardoso JMS, Félix MRF, Oliveira S, Clara MIE (2010) Multiplex RT-PCR for detection and identification of three necroviruses that infect olive trees. Eur J Plant Pathol 127:161-164

40. Vives MC, Rubio L, Galipienso L, Navarro L, Moreno P, Guerri J (2002) Low genetic variation between isolates of Citrus leaf 
blotch virus from different geographical origins. J Gen Virol 83:2587-2591

41. Woelk CH, Holmes EC (2002) Reduced positive selection in vector-borne RNA viruses. Mol Biol Evol 19(12):2333-2336
42. Youssef SA, Moawed SW, El-Sayed M, Shalaby AA, (2010) Detection of olive tree viruses in Egypt by one-step RT-PCR. In: 21st International Conference on virus and other graft transmissible diseases of fruit crops. Julius-Kuhn-Archiv, 427:51-55 